\title{
JoANNA MisZTAL-KONECKA
}

Katolicki Uniwersytet Lubelski Jana Pawła II

\section{ZAKAZ 'REFORMATIONIS IN PEIUS' \\ W POLSKIEJ PROCEDURZE CYWILNEJ WOBEC TRADYCJI PRAWA RZYMSKIEGO}

\section{WPROWADZENIE}

Częstokroć przypomina się o znaczeniu prawa rzymskiego dla tradycji prawa cywilnego materialnego, w cień usuwając jego wpływ na instytucje prawa procesowego ${ }^{1}$. A trzeba powiedzieć, że dzieje się tak niesłusznie, zapewne $\mathrm{z}$ uwagi na fakt naturalnego eksponowania zagadnień materialnoprawnych przed procesowymi. Wszak rozwiąza-

1 Literatura, nawet wyłącznie polska, poświęcona znaczeniu prawa rzymskiego dla współczesnego prawa jest ogromna. Tytułem przykładu, bez aspiracji do przedstawienia ogółu najistotniejszych pozycji, warto wspomnieć następujące prace: W. WoŁODKIEWICZ, Rzymskie korzenie współczesnego prawa cywilnego, Warszawa 1978; H. KuPIszewski, Znaczenie prawa rzymskiego dla współczesności, «PiP» 36.8/1981, s. 69-80; TenżE, Prawo rzymskie a współczesność, Warszawa 1988; M. KurYŁowicz, Historia i wspótczesność prawa rzymskiego, Lublin 1984; Tenże, Prawo rzymskie. Historia. Tradycja. Współczesność, Lublin 2003; W. WoŁodKIEWICz, Tradycja prawa rzymskiego we współczesnym prawie cywilnym, Palestra 31.10-11/1987, s. 66-85; P. Pogonowski, Znaczenie rzymskich paremii procesowych dla współczesnej procedury cywilnej, w: Starożytne kodyfikacje prawa. Materiaty z konferencji zorganizowanej 10-11 kwietnia 1999 r. w Lublinie, red. A. DĘBIŃski, Lublin 2000, s. 187-198; W. LITEWSKI, Podstawowe wartości prawa rzymskiego, Kraków 2001; T. GiAro, Cywilizacja prawa rzymskiego i problemy współczesnej romanistyki, «Acta Universitatis Wratislaviensis» 2008, «Prawo» 305 (Studia historycznoprawne. Tom poświęcony pamięci profesora Edwarda Szymoszka, red. A. KonIECZNY), s. 69-78; Prawo rzymskie a kultura prawna Europy, red. A. DĘBIŃski, M. JońCA, Lublin 2008; W. WoŁodKIEWICZ, Europa i prawo rzymskie. Szkice z historii europejskiej kultury prawnej, Warszawa 2009. 
nia przyjęte w rzymskim procesie cywilnym rządzą z mniejszymi lub większymi odchyleniami wszystkimi modelami postępowania cywilnego nie tylko w Europie, ale także poza nią². Jak słusznie zauważył H. Kupiszewski, jednym z dowodów żywotności prawa rzymskiego są maksymy (maximae, regulae, definitiones iuris), które wciela w życie współczesny ustawodawca i które bardzo często pojawiają się w wypowiedziach sędziów i stron procesowych ${ }^{3}$.

Jednym z najbardziej oczywistych dowodów zakresu oddziaływania prawa rzymskiego i łaciny na polskie prawo procesowe cywilne jest ilość paremii odnoszących się ściśle do uregulowań formalnoprawnych, umieszczonych na kolumnach gmachu Sądu Najwyższego ${ }^{4}$. Warto je zatem wymienić:

1. Non omnis vox iudicis iudicati continet auctoritatem (C.7,45,7 pr.) - Nie każda wypowiedź sędziego ma moc wyroku (kolumna 13);

2. Advocatorum error litigatoribus non noceat (C.2,9,3 pr.) - Błąd adwokatów niech nie szkodzi stronom (kolumna 14);

3. Nemo enim in persequendo deteriorem causam, sed meliorem facit $(\mathrm{D} .50,17,87)$ - Dochodzenie sprawy przed sądem nie może pogorszyć, lecz jedynie polepszyć sytuację powoda (kolumna 20);

4. Reformatio in peius iudici appellato non licet (ad D.49,1,1 pr.) - Sędziemu apelacyjnemu nie wolno zmieniać wyroku na niekorzyść odwołującego się (kolumna 26);

2 P. Pogonowski, Znaczenie ..., s. 188.

3 H. Kupiszewski, Prawo rzymskie ..., s. 113. Na ten temat por. także D. NöRr, Spruchregel und Generalisierung, ZSS 89(1972), s. 18-93; W. WoŁodKIEWICZ, Eacińskie paremie prawnicze w polskiej praktyce prawnej, [w:] Europa i prawo rzymskie. Szkice z historii europejskiej kultury prawnej, Warszawa 2009, s. 368-390, w tej pracy również szereg wskazówek bibliograficznych w zakresie badań nad znaczeniem rzymskich paremii, reguł i definicji.

4 Warto odnotować wzrost zainteresowania wpływem prawa rzymskiego na współczesne polskie prawo procesowe; por. np. K. AmielańczyK, J. ZaWrot, 'Nemo iudex in causa sua'. Wytaczenie sędziego w polskim postępowaniu cywilnym, "Gdańskie Studia Prawnicze» 26/2011, s. 61-77. 
5. Res iudicata pro veritate accipitur (D.50,17,207) - Rozstrzygnięcie sądowe przyjmuje się za prawdziwe (kolumna 45);

6. Nemo est iudex in propria causa (ad C.3,5,1) - Nikt nie może być sędzią we własnej sprawie (kolumna 66);

7. Reus in exceptione actor est (D. 44,1,1) - Pozwany w zakresie zarzutu procesowego staje się powodem (kolumna 72);

8. Ne eat iudex ultra petita partium (ad D.10,3,18) - Niech nie wychodzi sędzia ponad żądania stron (kolumna 74);

9. Nullus idoneus testis in re sua intellegitur (D.22,5,10) - Nikt nie może być wiarygodnym świadkiem we własnej sprawie (kolumna 75);

10. Sententia facit ius inter partes (ad D.5,2,17,1) - Wyrok tworzy prawo między stronami (kolumna 78);

11. Ei incumbit probatio qui dicit non qui negat (D.22,3,2) - Ciężar dowodu spoczywa na tym, kto twierdzi, a nie na tym, kto przeczy (kolumna 79);

12. Bis de eadem re ne sit actio (ad Gaium 4,107) - Nie można procesować się dwa razy o to samo (kolumna 80);

13. Actor rei forum sequitur (C.3,19,3) - Powód idzie do sądu (właściwego dla) pozwanego (kolumna 81);

14. Si in ius vocat, ito (Ustawa XII tablic) - Kto został wezwany przed sąd, niech się stawi (kolumna 83);

15. Favorabiliores rei potius quam actores habentur (D.50,17,125) - Korzystniejszą [sytuację procesową] mają pozwani niż powodowie (kolumna 86) .

\footnotetext{
5 K. AmielańczyK (U podstaw prawa prywatnego. „Rzymski proces cywilny” $i$ jego zasady. Uwagi na marginesie podręcznika prawa rzymskiego W. Dajczaka, T. Giaro i F. Longchampsa de Bérier, «Gdańskie Studia Prawnicze» 24/2010, s. 162) wskazuje, że więcej paremii umieszczonych na gmachu Sądu Najwyższego jest ściśle związanych z procesem cywilnym. Co ciekawe, w literaturze wskazano, że jedną z niesłusznie pominiętych paremii jest właśnie stwierdzenie odnoszące się do prawa procesowego, por. F. LONGCHAMPS DE BÉRIER, 'Audiatur et altera pars'. Szkic o braku-
} 
Stwierdzenie Reformatio in peius iudici appellato non licet, która wskazuje, iż sędziemu apelacyjnemu nie wolno zmieniać wyroku na niekorzyść osoby odwołującej się, oparte jest na wypowiedzi Ulpiana zawartej w pierwszej księdze o apelacjach (D.49,1,1pr.) ${ }^{6}$. Współczesnemu cywiliście zasada ta wydaje się oczywistością, przy czym oznacza ona zakaz pogorszenia sytuacji prawnej podmiotu poszukującego ochrony prawnej przez wniesienie środka zaskarżenia, jeżeli druga strona orzeczenia nie zaskarżyła ${ }^{7}$. W prawie rzymskim rozwiązanie to jednak nie było tak ewidentne. Warto zatem zestawić uregulowania rzymskie z obowiązującymi współcześnie, zwłaszcza że sporne jest $\mathrm{w}$ doktrynie nawet to, czy sam termin reformatio in peius pochodzi z prawa rzymskiego ${ }^{8}$.

\section{REFORMATIO IN PEIUS W RZYMSKIM POSTĘPOWANIU APELACYJNYM}

Powszechnie wiadomo, że w rozwoju rzymskiego procesu cywilnego wyróżnić można trzy etapy, poczynając od procesu legisakcyjnego, przez proces formułkowy, na postępowaniu kognicyjnym kończąc. $\mathrm{O}$ ile dwa pierwsze procesy nie przewidywały de facto procedury odwoławczej, o tyle w procesie kognicyjnym pojawiła się możliwość odwołania się (appellatio) do sądu wyższej instancji. Był to wówczas najważniejszy środek zaskarżenia i tego rodzaju funkcję zachował do dziś. Apelację wnoszono - w sprawach cywilnych, karnych, administracyjnych - do sądu wyższej instancji nad tym, który wydał zaskarżone orzeczenie (ad quem), składając ją za pośrednictwem

jącej kolumnie Pałacu Sprawiedliwości, [w:] 'Leges sapere'. Studia i prace dedykowane profesorowi Januszowi Sondlowi w pięćdziesiąta rocznice pracy naukowej, red. W. Uruszczak, P. Święcicka, A. Kremer, Kraków 2008, s. 271-283.

6 W. Litewski, Die römische Appellation in Zivilsachen (Ein Abriß), «ANRW» II.14, s. 92; K. BurCZAK, A. DĘBÍńsKI, M. JoŃCA, Lacińskie sentencje i powiedzenia prawnicze, Warszawa 2007, s. 187.

7 Na zgodność w polskiej i światowej literaturze postępowania cywilnego co do definicji zakazu reformationis in peius wskazuje P. PoGonowski, Zakaz 'reformationis in peius' w postępowaniu cywilnym, Warszawa 2004, s. 15-17.

8 K. MARSZAE, Zakaz 'reformationis in peius' w nowym ustawodawstwie karnym procesowym, Warszawa 1970, s. 22-23. 
tego ostatniego (a quo) w formie pisemnej lub też ustnie do protokołu sądowego. Składanie apelacji wiązało się z wysokimi kosztami, a niezasadność apelacji pociągała za sobą dodatkowe sankcje pieniężne. Istniały dwa rodzaje postępowania apelacyjnego - zwyczajny, polegający na ponownym rozpoznaniu sprawy z dopuszczeniem nowych twierdzeń, zarzutów i dowodów, oraz tzw. appellatio more consultationis skierowane do cesarza, polegające na nieograniczonej kontroli prawidłowości zaskarżonego wyroku na podstawie akt sprawy, za Justyniana dopuszczające także nowe twierdzenia, zarzuty i dowody. Sąd apelacyjny wydawał orzeczenie o zmianie zaskarżonego orzeczenia lub oddaleniu apelacji ${ }^{9}$.

Oczywiste jest, że dopiero w momencie pojawienia się postępowania wieloinstancyjnego (co najmniej dwuinstancyjnego) aktualizuje się problem zmiany orzeczenia na niekorzyść skarżącego.

W podręcznikach prawa rzymskiego niemal powszechnie wskazuje się, że w rzymskim postępowaniu apelacyjnym dopuszczalna była zmiana orzeczenia na mniej korzystne dla apelującego ${ }^{10}$. W konsekwencji warto zatem przyjrzeć się tekstom, które tego zagadnienia

9 Na ten temat por. np. T. KIPP, s.v. Appellatio. Im Civilprocess, «RE» 2, 194-208; R. Orestano, s.v. Appello. Diritto romano, «NNDI» 1,723-725; W. Litewski, Wybrane zagadnienia rzymskiej apelacji w sprawach cywilnych, Kraków 1967; TenżE, Studia nad rzymskim postępowaniem kognicyjnym, Kraków 1971; TENżE, Die römische Appellation..., s. 60-96; TenżE, Rzymski proces cywilny, Warszawa-Kraków 1988; W. OsuCHOwski, Rzymskie prawo prywatne. Zarys wykładu3, red. W. LiTEWsKi, J. Sondel, Warszawa 1988, s. 104-156; W. RozWAdowski, Prawo rzymskie. Zarys wykładu wraz z wyborem źródel, Poznań [b.r.w.], s. 57-84; W. LiTEwski, Rzymskie korzenie polskiej apelacji cywilnej, [w:] Księga pamiątkowa ku czci Witolda Broniewicza. 'Symbolae Vitoldo Broniewicz dedicatae', red. A. MArciniaK, Łódź 1998, s. 205-223; F. Pergami, L'appello nella legislazione del tardo impero, Milano 2000; W. WoŁodKIEWICZ, M. ZabŁocka, Prawo rzymskie. Instytucje ${ }^{5}$, Warszawa 2009, s. 279-323; F. Longchamps de Bérier, [w:] W. Dajczak, T. Giaro, F. Longchamps de Bérier, Prawo rzymskie. U podstaw prawa prywatnego, Warszawa 2009, s. 143-175; A. DĘBIŃsKi, Rzymskie prawo prywatne. Kompendium ${ }^{5}$, Warszawa 2011, s. 87-126.

10 W. Litewski, Die römische Appellation ..., s. 92; W. Osuchowski, op. cit., s. 155; W. RozWAdowski, op. cit., s. 82; W. LiteWsKI, Rzymskie korzenie ..., s. 221, 223; W. WoŁodkiewicz, M. ZabŁocka, op. cit., s. 314. Odmiennie jedynie F. Longchamps de Bérier, [w:] Prawo rzymskie..., s. 143-175; K. Amielańczyk, op. cit., s. 173; A. DĘ- 
dotyczą, rozpoczynając od wypowiedzi Ulpiana, w oparciu o którą stworzono tak często przywoływaną współcześnie paremię.

D. 49,1,1 pr. (Ulp., 1 de appel.): Appellandi usus quam sit frequens quamque necessarius, nemo est qui nesciat, quippe cum iniquitatem iudicantium vel imperitiam recorrigat: licet nonnumquam bene latas sententias in peius reformet, neque enim utique melius pronuntiat qui novissimus sententiam laturus est ${ }^{l 1}$.

W wypowiedzi Ulpiana znajduje się wyraźne stwierdzenie in peius reformet, które - wydałoby się - w prosty sposób łączy się z dzisiejszym terminem zakaz reformationis in peius. Tymczasem nie jest to stanowisko słuszne, skoro w rzeczywistości Ulpian analizuje w swojej wypowiedzi zalety i wady systemu apelacyjnego. Wśród niewątpliwych zalet wymienia możliwość poprawienia błędów popełnionych przez sędziego niższej instancji z powodu braku wiedzy, doświadczenia czy nawet z powodu niesprawiedliwości. Skoro zaś ocenia apelację jako często używaną i konieczną, niewątpliwie uważa, że przekazanie sprawy do sądu wyższej instancji pozwala żywić nadzieje na wyrok bardziej poprawny niż wydany uprzednio. Równocześnie jednak zauważa, iż brak jest gwarancji, by w instancji wyższej orzekała osoba dająca rękojmię niepopełnienia większego błędu, zdarza się bowiem zmiana wyroku niższej instancji na gorszy niż wydany poprzednio. Pomimo zatem założenia, że sąd wyższej instancji jest bardziej doświadczony, nie daje on pewności uzyskania lepszych wyników.

Ulpian porównuje zatem wyroki sądów niższej i wyższej instancji pod kątem zgodności z prawem i sprawiedliwością, stwierdzając, że zdarza się ,poprawa” wyroku przez sąd apelacyjny na gorszy, ale

BIŃSKI, op.cit., s. 174, którzy wiążą dopuszczalność zmiany orzeczenia na niekorzyść skarżącego dopiero z ustawodawstwem Justyniana.

11 Warto przytoczyć przykłady tłumaczeń tego tekstu: „Każdy wie jak częsta i konieczna jest apelacja, skoro poprawia ona niesprawiedliwość sądzących lub brak doświadczenia” (tł. W. RozWADOWSKI). „Jednakże zdarzyć się może, że dobre wyroki w apelacji na gorsze bywają zmienione. Może się zdarzyć, że sędzia najwyższej instancji wyda zły wyrok i zmieni na gorsze wyrok najlepszy” (tł. T. RowiŃski). 
nie w znaczeniu relacji do interesów skarżącego, natomiast gorszy w odniesieniu do zgodności z prawem materialnym i formalnym, ze sprawiedliwością. Rzymski prawnik nie odnosi się zatem w żaden sposób do kwestii zmiany wyroku sądu pierwszej instancji na mniej korzystny dla skarżącego. Trudno więc z jego wypowiedzi wywodzić współcześnie obowiązujący w procedurze cywilnej zakaz reformationis in peius ${ }^{12}$.

Tekst Ulpiana nie rozstrzyga, czy w procesie rzymskim obowiązywał, czy też nie obowiązywał zakaz pogorszenia sytuacji prawnej skarżącego na skutek rozpoznania wniesionej przez niego apelacji. Wydaje się jednak, że pośrednio na istnienie takiego zakazu wskazuje brzmienie lex Ampliorem z 530 roku.

W czasach przedjustyniańskich przedmiotem postępowania apelacyjnego były wyłącznie fragmenty orzeczenia zaskarżone przez apelującego $^{13}$. Istotną, w literaturze określaną nawet mianem największej ${ }^{14}$, zmianę przynosiła dopiero wspominana konstytucja cesarza Justyniana kierowana do prefekta pretorianów, Juliana.

C. 7,62,39 pr.-1: Imperator Justinianus: Ampliorem providentiam subiectis conferentes, quam forsitan ipsi vigilantes non inveniunt, antiquam observationem emendamus, cum in appellationum auditoriis in solus post sententiam iudicis emendationem meruerat, qui ad

12 P. Pogonowski, Zakaz 'reformationis in peius' w postępowaniu cywilnym ..., s. 24.

13 G. Sмyк, Zarys historycznego rozwoju zakazu reformationis in peius $w$ procesie cywilnym w czasach nowożytnych do końca XIX wieku, «Annales UMCS» 38/1991, Sectio G, s. 202.

14 F. Pergami, op. cit., s. 228. Nie można pominąć, że w literaturze powoływany jest fragment Res gestae Ammiana Marcelina (28,1,26: Circa hos dies Lollianus primae lanuginis adulescens, Lampadi filius ex praefecto, exploratius causam Maximino spectante, convictus codicem noxiarum artium nondum per aetatem firmato consilio descripsisse, exulque mittendus, ut sperabatur, patris inpulsu provocavit ad principem, et iussus ad eius comitatum duci, de fumo, ut aiunt, in flammam traditus Phalangio Baeticae consulari cecidit funesti carnificis manu), z którego wynika, iż w IV wieku zdarzył się przypadek zmiany wyroku na niekorzyść apelującego oskarżonego (szerzej dyskusję co do interpretacji tego testu omawia K. MArszaŁ, op. cit., s. 27-30). 
provocationis convolasset auxilium, altera parte, quae hoc non fecisset, sententiam sequi, qualiscumque fuisset, compellenda. (1) Sancimus itaque, si appellator semel in iudicium venerit et causas appellationis suae proposuerit, habere licentiam et adversarium eius, si quid iudicatis opponere maluerit, si praesto fuerit, hoc facere et iudiciale mereri praesidium: sin autem absens fuerit, nihilo minus iudicem per suum vigorem eius partes adimplere ${ }^{15}$.

Cesarz Justynian wprowadził w tej ustawie nowość, wyraźnie przeciwstawioną dotychczasowej praktyce, według której polepszenie sytuacji prawnej mogło nastąpić wyłącznie na rzecz osoby wnoszącej apelację. Wprawdzie ustawa z 530 roku nie przyniosła całkowitego złamania zakazu orzekania na niekorzyść apelującego, ale wprowadziła zasadę przyłączenia (ius adhaesionis), oznaczającą, że przeciwnik procesowy apelującego mógł przyłączyć się do zaskarżenia wyroku nawet po upływie terminu do wniesienia apelacji (wniesienie apelacji przez jedną ze stron pozwalało wprost drugiej stronie na kwestionowanie skarżonego wyroku). Odpowiadało to nieco pojęciu apelacji wzajemnej i powodowało, iż sąd nie był związany jedynie zarzutami wnoszącego apelację, ale również rozpoznawał racje wysunięte przez przeciwnika. Co więcej, w przypadku nieobecności przeciwnika procesowego skarżącego na rozprawie apelacyjnej ustawa nakazywała sędziemu brać pod uwage jego interesy i orzekać na jego korzyśćc ${ }^{16}$.

Trudno wszak uznać, że regulacja ta ukształtowała współczesną regulację zakazu reformatio in peius ${ }^{17}$, jeśli zważyć, że do pogorszenia sytuacji apelującego dochodziło na skutek swego rodzaju apela-

15 „Okazując poddanym naszą troskę, poprawiamy dawny obyczaj, wedle którego tylko ten zasługiwał na poprawę, kto wystąpił z apelacją. Nie widząc powodów, dla których druga strona, zmuszona jest podlegać takiemu wyrokowi, ustanawiamy, że jeśli apelujący stawił się w sądzie i przedstawił swoje żądania, to jego przeciwnik także musi mieć możliwość przedstawić swoje racje i wszelkie dowody mu znane oraz korzystać z pomocy sądu. Jeśli zaś będzie nieobecny, to sędzia ma obowiązek dopełnić jego praw" (tł. G. SмYк).

16 G. SMYк, op. cit., s. 202-203.

17 Sprzeczne poglądy w tej kwestii przywołuje K. MarszaŁ, op. cit., s. 26. 
cji wzajemnej przeciwnika lub działania sędziego ,zastępującego nieobecnego przeciwnika". De facto tylko w przypadku inicjatywy sędziego zachodziło orzekanie na niekorzyść ( $\mathrm{z}$ urzędu).

Rozwój prawa rzymskiego zakończył się zatem przyjęciem przeciwieństwa współczesnej reguły. Co istotne, właśnie konstytucja Justyniana z 530 roku wywarła początkowo największy wpływ na rozwój procesu cywilnego niemieckiego $\mathrm{z}$ racji na recepcję prawa rzymskiego, w którym do XVIII/XIX w. we współczesnym rozumieniu zakaz reformationis in peius nie obowiązywat ${ }^{18}$. W konsekwencji całkowicie słuszne jest stwierdzenie G. Smyka, że nawet termin zakaz reformationis in peius nie jest terminem źródłowym pochodzącym z prawa rzymskiego, ale sztucznym pojęciem prawniczym wywodzącym się $\mathrm{z}$ łaciny ${ }^{19}$.

\section{REgUlACJE POLSKIEJ PROCEDURY CYWILNEJ}

Na gruncie kodeksu postępowania cywilnego z 1932 roku, idącego wyraźnie wzorem krajów germańskich, choć brak było wyraźniej regulacji, powszechnie przyjmowano, że w prawie polskim obowiązuje zakaz reformationis in peius, a wywodzono go z zasady dyspozycyjności ${ }^{20}$. Zakaz reformatio in peius jest natomiast wyraźnie przewidziany w art. 384 k.p.c. ${ }^{21}$, stosownie do którego sąd nie może uchylić lub zmienić wyroku na niekorzyść strony wnoszącej apelację, chyba że strona przeciwna również wniosła apelację $e^{22}$. Regulacja ta jest istot-

18 Szerzej por. P. Pogonowski, Zakaz 'reformationis in peius' $w$ postepowaniu cywilnym ..., s. 27-29.

19 G. SMYK, op. cit., s. 201.

20 Por. T. RowiŃski, Zakres mocy wiążacej zakazu 'reformationis in peius' w polskim procesie cywilnym, «Zeszyty Naukowe Uniwersytetu Łódzkiego Nauki Humanistyczno-Społeczne» 37/1964, s. 141 wraz z powołaną wcześniejszą literaturą; K. PIASECKI, Zakaz 'reformationis in peius' w procesie cywilnym, «Palestra»12.9/1967, s. 16; P. Pogonowski, Zakaz 'reformationis in peius' w postepowaniu cywilnym ..., s. 35-38.

${ }^{21}$ Ustawa z dnia 17 listopada 1964 r. - Kodeks postępowania cywilnego (Dz. U. z 2014 r., poz. 101 ze zm.).

22 Zakaz reformationis in peius z art. 384 k.p.c. obowiązuje także w postępowaniu adhezyjnym. Por. szerzej P. Pogonowski, Zakaz 'reformationis in peius' w postepowa- 
nym ograniczeniem kognicji sądu odwoławczego, a jednocześnie gwarancją dla skarżącego pozwalającą na nieskrępowane skorzystanie ze środka odwoławczego ${ }^{23}$. W starszej literaturze wśród powodów wprowadzenia tego zakazu wymieniano fakt zgody drugiej strony na treść wydanego orzeczenia (tzw. teoria słusznie nabytego prawa), swego rodzaju uprawomocnienie się orzeczenia w niezaskarżonym aspekcie (tzw. teoria względnej prawomocności), to, że środki odwoławcze służą interesowi stron, a więc mają prowadzić do usunięcia tylko tych uchybień, które krzywdzą stronę (uzasadnienie $\mathrm{z}$ istoty środka odwoławczego), a nadto zakaz orzekania ponad żądanie stron (uzasadnienie z zasady dyspozycyjności) ${ }^{24}$.

Oczywiste jest, że ratio zakazu odpada w sytuacji wniesienia środka odwoławczego przez obie strony (lub kilku uczestników postępowania nieprocesowego, których interesy są sprzeczne), skoro nie jest możliwe rozstrzygnięcie korzystne dla obu stron. W konsekwencji, w razie niewniesienia apelacji przez stronę przeciwną, skarżący naraża się wyłącznie na oddalenie jego apelacji i obciążenie kosztami postępowania apelacyjnego. Gdy zaś druga ze stron skutecznie apelację wywiodła, to jej uwzględnienie w sposób oczywisty pogarsza sytuację skarżącego. W doktrynie wskazano, że zakaz reformatio in peius uchyla samo wniesienie apelacji przez stronę przeciwną, o ile jest skuteczne, a zatem apelacja przeciwnika odrzucona z przyczyn formalnych zakazu orzekania na niekorzyść skarżącego nie niweczy ${ }^{25}$.

W doktrynie polskiego postępowania cywilnego dominuje pogląd, że do naruszenia zakazu reformationis in peius może dojść tylko przez

niu adhezyjnym, «Prokuratura i Prawo» 11/2005, s. 157-165.

23 Szerzej por. T. Rowiński, Motywy 'zakazu reformationis in peius' $w$ polskim procesie cywilnym, «Zeszyty Naukowe Uniwersytetu Łódzkiego. Nauki Humanistyczno-Społeczne» 31/1963, s. 141.

24 Poglądy na temat uzasadnienia zakazu reformationis in peius szeroko przedstawiają T. Rowiński, Motywy ..., s. 133-144; G. SMYK, op. cit., s. 206-207; P. PoGONowSKI, Zakaz 'reformationis in peius' w postępowaniu cywilnym ..., s. 43-77.

25 Tamże, s. 81-82. 
orzekanie sądu drugiej instancji co do istoty sprawy ${ }^{26}$, naruszenie takie nie zachodzi natomiast $\mathrm{w}$ razie zastąpienia niekorzystnego orzeczenia procesowego innym niekorzystnym orzeczeniem procesowym, np. gdy w razie odrzucenia pozwu przez sąd pierwszej instancji sąd drugiej instancji umorzy postępowanie, a nawet gdy niekorzystne orzeczenie procesowe zastąpi niekorzystnym orzeczeniem merytorycznym. Podobnie nie ma pogorszenia sytuacji strony, gdy orzeczenie merytoryczne niekorzystne dla skarżącego zostanie zastąpione przez sąd drugiej instancji niekorzystnym orzeczeniem procesowym ${ }^{27}$. Sporne jest natomiast, czy można naruszyć art. 384 k.p.c. poprzez uchylenie wyroku i przekazanie sprawy do ponownego rozpoznania ${ }^{28}$.

Wydaje się oczywiste, że przy ponownym rozpoznaniu sprawy zakaz reformationis in peius obowiązuje, ponieważ w istocie byłby on iluzoryczny, skoro nie dawałby skarżącemu pewności niepogorszenia sytuacji w ostatecznym rozstrzygnięciu ${ }^{29}$. Nie oznacza to wszakże zakazu

26 S. HANAUSEK, [w:] System prawa procesowego cywilnego, III: Zaskarżanie orzeczeń sądowych, red. W. Siedlecki, Wrocław-Warszawa 1986, s. 287; P. Pogonowski, Zakaz 'reformationis in peius' w postępowaniu cywilnym ..., s. 129; A. GóRA-BŁAszczYKowskA, Apelacja. Zażalenie. Wznowienie postepowania. Skarga o stwierdzenie niezgodności z prawem prawomocnego orzeczenia. Komentarz, Warszawa 2006, s. 115.

27 Postanowienie Sądu Najwyższego z dnia 21 lutego 1997 r., I PKN 19/97, «OSNP»1997/23/466. Tak uprzednio K. PIASECKI, Zakaz ..., s. 24-25; T. Rowiński, Zakres mocy wiązacej zakazu 'reformationis in peius' $w$ polskim procesie cywilnym..., s. 129; B. DobrZAŃSKI, Wybrane zagadnienia proceduralne, Katowice 1969/70, s. 37.

28 P. Pogonowski, Zakaz 'reformationis in peius' $w$ postepowaniu cywilnym ..., s. 129, wskazuje, że w takim przypadku nie obowiązuje zakaz reformationis in peius. Natomiast B. Dobrzański, op. cit., s. 35; T. EREciŃSKI, Kodeks postępowania cywilnego. Komentarz. Postępowanie rozpoznawcze ${ }^{4}$, II, red. T. ERECIŃsKI, Warszawa 2012, s. 255 i K. PIASECKI, [w:] Kodeks postępowania cywilnego ${ }^{5}$, II: Komentarz do artykułów 367-505 $5^{37}$, red. K. PIASECKI, Warszawa 2010, s. 48-49 - uważają, że nie można uchylić wyroku z uwagi na nieważność postępowania na niekorzyść apelującego (podobnie uchwała Sądu Najwyższego z dnia 7 marca 1968 r., III PZP 2/68, «Lex» nr 6296).

29 T. RowiŃSKI, Zakres mocy wiążacej zakazu 'reformationis in peius' $w$ polskim procesie cywilnym..., s. 130-131. Tak też wyrok Sądu Najwyższego z dnia 7 grudnia 2007 r., III CSK 234/07, «Lex» nr 487539. Odmiennie por. K. PIASECKI, Zakaz ..., s. 20; B. Dobrzański, op. cit., s. 36, 40-45; P. Pogonowski, Zakaz 'reformationis in peius' w postępowaniu cywilnym ..., s. 146-149. 
zmiany powództwa przez powoda, a zwłaszcza jego rozszerzenia ${ }^{30}$, co w praktyce może istotnie podważyć gwarancyjny charakter omawianego zakazu.

W orzecznictwie brak jednolitego stanowiska co do tego, czy zakaz reformationis in peius wyklucza poczynienie mniej korzystnych dla skarżącego ustaleń faktycznych ${ }^{31}$, czy też nie ma podstaw do rozszerzania zakazu reformationis in peius na sferę motywacyjną korzystnego dla skarżącego orzeczenia ${ }^{32}$. Pozo sporem pozostaje natomiast pogląd, że zakaz reformationis in peius nie obejmuje samej zmiany podstawy prawnej orzeczenia na mniej korzystną ${ }^{33}$.

Przykładem naruszenia zakazu reformationis in peius jest przyspieszenie terminów płatności rat $^{34}$, niekorzystna zmiana co do roszczenia głównego, co do odsetek, co do kosztów za pierwszą instancję ${ }^{35}$, zmiana

30 Z. Resich, Glosa do orzeczenia Sadu Najwyższego z dnia 27 stycznia 1960 r., 3 CR 916/59; «OSPiKA» 9/1960, s. 567; E. WENGEREK, Przegląd orzecznictwa Sadu Najwyższego w zakresie procesu cywilnego (II pótrocze 1960 r.), «NP» 33.7-8/1961, s. 925.

31 Wyrok Sądu Najwyższego z dnia 10 kwietnia 1967 r., II PR 32/67, «Lex» nr 6136; wyrok Sądu Najwyższego z dnia 2 lipca 1991 r., III CRN 33/91, «Lex» nr 9061 .

32 Wyrok Sądu Najwyższego z dnia 5 września 2002 r., II CKN 831/00, «Lex» nr 74404. Tak też B. DobrzańsKi, op. cit., s. 35.

33 T. Rowiński, Zakres mocy wiążacej zakazu reformationis in peius $w$ polskim procesie cywilnym..., 145-146. Tak też wyrok Sądu Najwyższego z dnia 12 października 2007 r., V CSK 261/07, «Lex» nr 497671; postanowienie Sądu Najwyższego z dnia 12 listopada 2008 r., I UK 206/08, «Lex» nr 737381.

34 Wyrok Sądu Najwyższego z dnia 7 kwietnia 2004 r., IV CK 215/03, «Lex» nr 152889.

35 B. DobrZAŃSKI, op. cit., s. 35. Odmiennie por. jednak T. RowińsKi, Zakres mocy wiążacej zakazu 'reformationis in peius' $w$ polskim procesie cywilnym..., s. 146 oraz postanowienie Sądu Najwyższego z dnia 22 czerwca 2010 r., IV CZ 42/10, «OSNC-ZD» 2011/2/26, gdzie wyrażono stanowisko, iż zakaz nie obejmuje takich elementów, jak koszty postępowania lub rygor natychmiastowej wykonalności, ponieważ nie są to rozstrzygnięcia co do istoty sprawy. Jeżeli zatem sąd odwoławczy orzeka o ,procesie” bez rozstrzygnięcia sprawy co do meritum, nie można w zasadzie mówić o uchyleniu lub zmianie wyroku na niekorzyść, choćby sąd nie uwzględnił wniosków skarżącego. To oznacza, że orzeczenie o kosztach procesu może być zmienione na niekorzyść skarżącego, tak jak i skarżący może zostać zobowiązany do zwrotu kosztów postępowania apelacyjnego. 
wyroku ustalającego istnienie lub nieistnienie prawa lub stosunku prawnego na wyrok zasądzający świadczenia na niekorzyść skarżącego ${ }^{36}$.

Nie zawsze jednak ocena położenia strony procesowej, jej interesu w zaskarżeniu orzeczenia, a w konsekwencji zakresu zakazu pogorszenia jej sytuacji procesowej jest jednoznaczna. Wydaje się, że słusznie dopuszcza się możliwość żądania uchylenia korzystnego dla strony orzeczenia wydanego $\mathrm{w}$ warunkach nieważności postępowania. W takim przypadku interes strony w zaskarżeniu tego orzeczenia będzie polegać na wyeliminowaniu orzeczenia, które może być w przyszłości zakwestionowane przez stronę pozwaną z powodu jego nieważności i uchylone w wyniku wznowienia postępowania, wraz ze skutkami w postaci np. zwrotu spełnionego świadczenia, kosztów postępowania itp. Zatem o dopuszczalności zaskarżenia przez stronę orzeczenia decyduje nie tylko utrata korzyści prawnej będąca skutkiem tego orzeczenia, istniejąca $\mathrm{w}$ chwili zaskarżenia orzeczenia, ale także obawa utraty korzyści w przyszłości, choćby orzeczenie sądu pierwszej instancji w chwili jego wydania było dla strony korzystne. Ma to miejsce wówczas, gdy strona nie ma innej drogi dla ustrzeżenia się przed niekorzystnymi dlań skutkami wyroku uwzględniającego jej powództwo, jak tylko przez jego zaskarżenie ${ }^{37}$.

$\mathrm{W}$ postępowaniu procesowym zakaz reformationis in peius nie dotyczy przypadków, w których sąd władny jest orzekać z urzędu na mocy przepisów szczególnych, np. co do zawarcia w złej wierze małżeństwa w warunkach uzasadniających jego unieważnienie (art. 20 § 1 k.r.o.), co do winy rozkładu pożycia w sprawach rozwodowych (art. $57 \S 1$ k.r.o.), co do władzy rodzicielskiej w sprawach rozwodowych (art. $58 \S 1$ k.r.o. $)^{38}$. Stąd też np. w razie wniesienia apelacji od wyroku

36 S. Hanausek, op. cit., s. 289. Tak też uchwała Sądu Najwyższego z dnia 26 kwietnia 1974 r., III PZP 10/74, «OSNC» 1974/10/168. Odmiennie por. E. WENGEREK, Przegląd orzecznictwa Sądu Najwyższego z zakresu procesu cywilnego (za rok 1974), «NP» 31.6/1975, s. 878-879.

37 Orzeczenie Sądu Najwyższego z dnia 7 lutego 1962 r., 2 CR 763/60, «OSPiKA» 4/1963, poz. 102. Por. też S. Hanausek, op. cit., , s. 288.

38 T. RowiŃski, Zakres mocy wiążacej zakazu 'reformationis in peius' w polskim procesie cywilnym..., s. 125-129; S. HANAUSEK, op. cit., s. 287-288; T. ERECIŃSKI, op. 
orzekającego rozwód w części dotyczącej winy rozkładu pożycia małżeńskiego tylko przez jednego małżonka, sąd drugiej instancji może $\mathrm{z}$ urzędu orzec w tym zakresie także na niekorzyść tego małżonka ${ }^{39}$.

Zakaz reformationis in peius obowiązuje także w postępowaniu nieprocesowym, o tyle stosowany tam może być jedynie „odpowiednio" 40 . Dotyczy on zwłaszcza tych spraw, gdy sporny stosunek pomiędzy uczestnikami czyni z nich w istocie „strony przeciwne"41. Jednakże nawet wówczas - zasada związania sądu zakazem reformationis in peius podlega wyłączeniu w odniesieniu do spraw, w których sąd orzeka z urzędu, a zatem w tych sytuacjach, w których wszczęcie postępowania nieprocesowego może nastąpić z urzędu, bądź w tych, w których wprawdzie wszczęcie postępowania może nastąpić tylko na wniosek, ale na podstawie szczególnych przepisów sąd ma obowiązek orzekać w pewnym zakresie z urzędu.

W konsekwencji słusznie wywiedziono, iż w sprawach działowych (podział majątku wspólnego, dział spadku, zniesienie współwłasności) z uwagi na charakter orzeczenia, w którym poszczególne rozstrzygnięcia są ze sobą istotowo powiązane możliwe jest uchylenie lub zmiana rozstrzygnięcia na niekorzyść skarżącego, jeżeli przedmiot zaskarżenia jest integralnie związany z inną częścią lub całością zaskarżonego

cit., s. 255.

39 Orzeczenie Sądu Najwyższego z dnia 13 maja 1957 r., 3 CR 56/56, «OSN» 1958/2/48; wyrok Sądu Najwyższego z dnia 19 stycznia 2005 r., V CK 364/04, «OSNC» 2005/12/218. Warto odnotować istotne przemiany pojmowania zakazu reformationis in peius w sprawach rozwodowych (szerzej por. P. PoGonowski, Wybrane problemy tzw. integralności (niepodzielności) wyroku rozwodowego. Zakaz 'reformationis in peius' w postepowaniu rozwodowym, «Palestra» 49.7-8/2004, s. 40-53), a zwłaszcza fakt, iż obecnie uznaje się, że jedynie w przypadku zaskarżenia wyroku rozwodowego/separacyjnego co do winy, możliwe jest orzekanie na niekorzyść skarżącego, w razie zaś zaskarżenia rozstrzygnięć dotyczących korzystania ze wspólnego mieszkania czy alimentacji zakaz reformationis in peius obowiązuje w całej pełni.

40 S. HANAuSEK, op. cit., s. 288. Tak też postanowienie Sądu Najwyższego z dnia 29 stycznia 2008 r., IV CSK 432/07, «Lex» nr 492176.

41 B. Bladowski, Środki odwoławcze w postęowaniu cywilnym ${ }^{3}$, Warszawa 2008, s. 118 . 
orzeczenia ${ }^{42}$. Istotna niepodzielności orzeczenia polega bowiem na tym, że czasami nie sposób dokonać korekty jednego (scil. zaskarżonego) rozstrzygnięcia bez odpowiedniej modyfikacji innego. W szczególności zaskarżenie przez uczestnika postępowania, któremu został przyznany przedmiot działu na własność, orzeczenia sądu I instancji w części orzekającej o spłatach może uzasadniać uchylenie orzeczenia także w części orzekającej o przyznaniu własności, jeżeli obrona skarżącego przed wysokimi, ale prawidłowo ustalonymi spłatami może uzasadniać bądź przyznanie mu tylko części przedmiotu działu, bądź nawet przyznanie go innym uczestnikom. Jeżeli zaś zarzuty apelacyjne godzą w samą zasadę działu, to zachodzi konieczność przeprowadzenia nowej oceny projektu działowego, a także nowych wyliczeń. Konieczna jest zatem ocena z punktu widzenia całości działu, a nie jego fragmentu. Będzie ona prawidłowa i trafna tylko wtedy, gdy sąd drugiej instancji, nie bacząc na granice wniosków apelacyjnych, lecz pamiętając o obowiązującej w tym postępowaniu zasadzie oficjalności, uwzględni mienie należące do spadku, które np. sąd pierwszej instancji pominął.

Podobnie treść art. 677 § 1 k.p.c. oraz charakter postępowania o stwierdzenie nabycia spadku wyłączają w tym postępowaniu zakaz reformationis in peius ${ }^{43}$.

Wprawdzie zakaz pogarszania sytuacji prawnej skarżącego jest charakterystyczny dla postępowania rozpoznawczego, jednak po myśli art. $13 \S 2$ k.p.c. znajduje także zastosowanie w postępowaniu zabez-

42 Uchwała Sądu Najwyższego z dnia 11 marca 1977 r., III CZP 7/77, «OSNC» 1977/11/205; postanowienie Sądu Najwyższego z dnia 17 września 1999 r., I CKN 379/98, «OSNC» 2000/3/59; postanowienie Sądu Najwyższego z dnia 28 marca 2003 r., IV CKN 1961/00, «Lex» nr 80241; postanowienie Sądu Najwyższego z dnia 5 marca 2008 r., V CSK 447/07, «Lex» nr 577238. Odmiennie por. uchwała Sądu Najwyższego z dnia 13 maja 1968 r., III CZP 19/68, «OSNCP» 1968/12/205.

43 Uchwała Sądu Najwyższego z dnia 26 października 1973 r., III CZP 13/73, «OSNCP» 1974/9/144; postanowienie Sądu Najwyższego z dnia 6 maja 2005 r., II CK 676/04, «Lex» nr 603159. Odmiennie por. Uchwała Sądu Najwyższego z dnia 13 maja 1968 r., III CZP 19/68, «OSNC» 1968/12/205. 
pieczającym i egzekucyjnym ${ }^{44}$. Zdaniem P. Pogonowskiego, sąd odwoławczy jest związany zakazem reformationis in peius $\mathrm{w}$ razie wniesienia zażalenia w sytuacjach wskazanych w art. 768 k.p.c., art. 770 k.p.c., art. $807 \S 1$ k.p.c., art. 839 k.p.c., art. 1028 § 3 k.p.c., art. 1037 $\S 1$ k.p.c., art. 1055 k.p.c., art. $1061 \S 2$ k.p.c., w innych przypadkach bowiem $\mathrm{z}$ istoty rzeczy wykluczone jest pokrzywdzenie skarżącego ${ }^{45}$.

\section{Podsumowanie}

Apelacja była oryginalnym tworem rzymskim. Obecne uregulowanie apelacji sięga swymi korzeniami pośrednio do apelacji rzymskiej - poczynając od samej nazwy (appellatio - apelacja), przez przedmiot zaskarżenia (wyroki i niektóre postanowienia) czy charakter dewolutywny. Nie oznacza to, że konstrukcja tego środka odwoławczego przewidziana $\mathrm{w}$ polskim kodeksie postępowania cywilnego stanowi niezbite świadectwo tego, że w postaci poklasycznej rzymski proces przetrwał upadek Rzymu i oddziałując na proces kanoniczny, odcisnął niezatarte piętno na wielu europejskich procedurach cywilnych.

Jednym $\mathrm{z}$ wyjątków w tym zakresie jest właśnie przyjęcie odmiennego niż w prawie justyniańskim rozwiązania w postaci zakazu reformationis in peius. Prawo rzymskie justyniańskie takiego zakazu nie przewidywało. Tymczasem w prawie polskim przyjmuje się, że sytuacja prawna skarżącego nie może ulec pogorszeniu, jeśli przeciwnik nie wniósł środka odwoławczego. Uwalnia go to od obawy, że samo uruchomienie procedury odwoławczej może doprowadzić do pogorszenia jego sytuacji. Choć zagadnienie zakresu obowiązywania przedmiotowego zakazu pozostaje przedmiotem licznych kontrowersji zasygnalizowanych w niniejszym artykule, warto w skrócie wskazać, że zakaz ten adresowany jest wyłącznie do sądu (choć sporne jest, czy tylko do sądu rozpoznającego środek odwoławczy, czy również

44 Szerzej por. P. Pogonowski, Zakaz 'reformationis in peius' w postepowaniu zabezpieczajacym i egzekucyjnym, «Przegląd Prawa Egzekucyjnego» 3-4/2004, s. 31-50; B. BladowsKi, Zażalenie w postępowaniu cywilnym ${ }^{4}$, Kraków 2006, s. 117.

45 P. Pogonowski, Zakaz 'reformationis in peius' $w$ postępowaniu zabezpieczajacym ..., s. 46-47. 
do sądu pierwszej instancji rozpoznającego sprawę po jej przekazaniu do ponownego rozpoznania); obejmuje tylko przypadki wniesienia apelacji przez jedną ze stron procesu; nie odnosi się do przypadków, w których sąd może lub musi orzekać z urzędu; rozciąga się jedynie na dewolutywne środki zaskarżenia; obejmuje wyłącznie orzeczenia co do istoty sprawy.

Prohibition of 'Reformatio in peius' in Polish Civil Procedure in the Light of THE TRADition OF Roman LaW

\section{Summary}

The subject of this paper is an assessment of the influence of Roman law on the contemporary regulations for appeal in Polish civil procedure as regards the prohibition of reformatio in peius. The author's analysis shows that despite the general belief that the ban on the worsening of the appellant's situation in the event of the opposite party failing to lodge an appeal derives from Roman roots, in fact when used in the context of the way in which Polish appeal courts deliver a verdict, the expression reformatio in peius is nothing more than an artificial legal concept derived from Latin.

Słowa kluczowe: reformatio in peius, apelacja, zakaz pogarszania sytuacji skarżącego, prawo rzymskie

Keywords: reformatio in peius, ban on the worsening of the appellant's situation, Roman law 